\title{
GELATIN IKAN: SUMBER, KOMPOSISI KIMIA DAN POTENSI PEMANFAATANNYA
}

\author{
Agnes Triasih Agustin \\ Fakultas Perikanan dan Ilmu Kelautan, Universitas Sam Ratulangi, Manado, Sulawesi Utara.
}

\begin{abstract}
ABSTRAK
Gelatin bagi Industri di Indonesia permintaan semakin meningkat, karena gelatin ini banyak dimanfaatkan pada industri farmasi, pangan dan non pangan. Permintaan meningkat untuk industry dapat dilihat dari adanya impor pada tahun 2002 dari 2.144 ton menjadi 6.233 ton pada tahun 2003, sewdangkan statistik pada januari- desmber 2009, pemerintah mengimpor gelatin sebesar $3.124 .255 \mathrm{~kg}$ dengan nilai impor mencapai US\$ 16.741.918. Gelatin ini diimpor dari Negara China, Jepang, Jerman, Perancis da Australia. Gelatin yang dimpor oleh pemerintah hamper $90 \%$ yang digunakan, adapun gelatin impor diketahui diproduksi dengan bahan baku kulit babi, kulit sapid an tulang sapi. Gelatin dari ikan adalah hasil hidrolisa protein yang terdapat pada tulang ikan, kulit ikan.
\end{abstract}

Kata kunci: gelatin, tulang ikan, kulit ikan.

\section{PENDAHULUAN}

Di Indonesia kebutuhan akan gelatin semakin meningkat, terlihat dari jumlah impor tahun 2002 sebesar 2.144 ton, tahun 2003 sebesar 6.233 ton (Anonim, 2007). Impor yang dilakukan oleh pemerintah Indonesia secara statistik dalam kurun waktu Januari- Desember 2009 telah mengimpor sebesar $3.124 .255 \mathrm{~kg}$ dengan nilai impor mencapai US\$ 16.741 .918 (Anonim, 2007). Gelatin yang diimpor dari China, Jepang, Perancis, Australia, India dan Selandia Baru. Penggunaan gelatin secara keseluruhan yang diimpor, hampir $90 \%$ adalah diproduksi dari bahan baku kulit babi, kulit sapid an tulang sapi. Penggunaan bahan baku dari kulit babi, tentunya akan menimbulkan masalah bagi masyarakat Indonesia yang mayoritas pendudukanya beragama Islam, sedangkan untuk bahan baku dari ternak sapi, menimbulkan masalah bagi masyarakat yang menganut agama Hindu.

Pada tahun-tahun terakhir, para peneliti sudah banyak yang meneliti sumber-sumber bahan baku yang sifatnya halal, higienis dan dapat diterima oleh berbagai penganut agama. Jenis bahan baku gelatin yang saat ini telah banyak diteliti yaitu dari tulang ikan dan dari kulit ikan. Tulang ikan dan kulit ikan adalah hasil limbah yang belum dimanfatkan secara maksimal, dari hasil industri ikan tuna loin di Bitung Sulawesi Utara. Limbah ikan tuna yang belum dimanfaatkan dapat mencemari lingkungan dengan bau yang menyengat maupun banyak lalat disekitarnya, bagi para penampung limbah ini yang hanya dimanfaatkan untuk pakan ternak, pakan ini didapat dari limbah yang hanya dijemur dengan panas matahari. Limbah industri ikan tuna loin dapat dipergunakan sebagai bahan baku pembuatan gelatin ikan, sekaligus dapat mengatasi limbahnya dan dapat dikembangkan usaha pengolahan gelatin ikan untuk memperoleh nilai ekonomis yang tinggi dan mempunyai daya saing industri dalam bidang perikanan.

\section{SUMBER GELATIN IKAN}

Protein adalah zat bermolekul dalam sel mahluk hidup, fungsi biologis protein dapat disebutkan dimana tempat terdapatnya dan nama biologisnya seperti fungsi biologis yaitu nama srtuktural sebagai keratin, kolagen dan elastin, ini nterdapat sebagai jaringan ikat, tulang rawan, rambut dan kulit. Ikan tuna yang ada di Sulawesi Utara yang diekspor ke Negara lain adalah berupa tuna loin, maka ekspor filet yang besar jumlahnya, maka dapat diasumsikan jumlah kulit tuna sebagai by produk yang diperkirakan sejumlah $12 \%$, maka dapat diperoleh gelatin yang jumlahnya besar juga ( Wahyuni, $M$ dan Peranginangin,2008) lebih lanjut dikatakan bahwa gelatin juga didapat dari ikan yang bertulang keras.

\section{GELATIN IKAN}

Gelatin adalah ikatan polipeptida yang dihasilkan dari hidrolisa kolagen tulang, kulit yang adalah turunan protein dari serta kolagen, 
secara fisik dan kimia adalah sama. Dapat dikatakan juga bahwa gelatin adalah hasil dari denaturasi kolagen. Hidrolisa tergantung pada cross-link antara ikatan peptide dan grup-grup asam amino yang reaktif yang terbentuk (Ockerman dan Hansen, 2000). Anonimous (2000) mengatakan bahwa gelatin adalah derivat dari kolagen yang ditemukan pada kulit dan tulang. Gelatin yang dengan air apabila dipanaskan akan membentuk gel pada temperature di bawah $35^{\circ} \mathrm{C}$, ini unik karena sesuai dengan suhu tubuh manusia (Anonimous, 2005). Dipasaran gelatin dikelompokan secara komersial adalah gelatin tipe A dan tipe B.

\section{STRUKTUR DAN SIFAT-SIFAT KIMIA GELATIN}

Philip I Rose (1992) mengatakan bahwa bahan mentah yang berbasis protein molekul kolagen, dimana masing-masing molekul kolagen mengandung ikatan polipeptida yang disebut ikatan alfa dimana left-handed dalam bentuk helix, kolagen mengikat triple-helix ini mungkin terjadi, karena masing-masing ikatan berisi perbedaan sequence dari asam amino triple yang diulang-ulang yakni (Glycine-X-Y) dimana $\mathrm{X}$ dan $\mathrm{Y}$ masing-masing adalah prolin dan hidroxyprolin. Struktur kimia gelatin adalah $\left(\mathrm{C}_{102} \mathrm{H}_{151} \mathrm{~N}_{31}\right)$, didalamnya adalah asam amino seperti 14\% Hidroxyprolin, 16\% Prolin, $26 \%$ Glysine, kandungannya tergantung dari bahan mentahnya (Ockerman dan Hansen, 2000), dikatakan juga bahwa asam amino pada kulit ikan Cod mengandung asam amino Alanin,Arginin, Asam aspartat, Sistein, Glutamin, Glysin, Histidin Hidroxyprolin, Isoleusin, kandungan tertingginya Glisin. Menurut Gomez et al. (2002) bahwa beberapa gelatin dari ikan, dikatakan komposisi asam aminonya tidaklah besar perbedaannya, pada alami dan hidroxylasinya. Asam amino dari ikan Bigeye Snapper dan Brownstrip red snapper adalah kaya akan glisin, alanin, prolin dan hidroxyprolin, selanjutnya dikatakan bahwa hidroxyprolin memainkan peranan penting pada stabilitas dari triple-triple helix melalui ikatan hydrogen yang turun ke grup $-\mathrm{OH}$ (Jongjareonrak, 2006). Gelatin bersifat padat, terang, rapuh, agak kekuningan sam,pai jernih dan tidak berbau, mengandung 9 asam amino essensial yaitu: Leusin, Sistein, Methionin, phenilalanin, Serin, Valin, Threonin, Isoleusin dan Tirosin (Anonimous, 2006). Asam amino pada anjing laut juga hamper sama komposisinya yaitu: Asam Aspartat, Hydroxyprolin, Threonin, Serin, Leusin,Tirosin, Prolin, Phenilalanin,Valin, Methionin, Alanin, Lisin, Histidin dan Arginin (Arnesen and Gildberg, 2001). Sifat gelatin adalah mempunyai titik isoelektrik 7,0-9,5 , Ph 3,86,0, kekuatan gel (g) 75-300, viskositas(mp) $20-75$ dan kandungan abu $0,3-2,0 \%$.

\section{MANFAAT DAN FUNGSI GELATIN}

Pada industri pangan banyak memanfaatkan industri gelatin, antara lain dalam produk yang memerlukan pembentukan busa (whipping agent), biasanya pada pembuatan es krin, sedang produk yang perlu menstabilkan pada hasilnya, maka gelatin ini berfungsi sebagai stabilizer. Ada produk yang memerlukan gelatin ini untuk meningkatkan viskositas dan juga berfungsi sebagai pengikat (binder), juga emulsifier dan thickener (Wahyuni dan Peranginangin, 2008). Pada bidang fotografi, maka gelatin digunakan untuk memperpanjang daya simpan dalam menyimpan foto, yaitu sebagai fotoresist yang dapat menghindari (coating) dari adanya cahaya yang sensitif (Ockerman and Hansen, 2000), selanjutnya dikatakan bahwa pada proses fotografi adalah baik menggunakan gelatin ikan, karena mempunyai kekuatan gel yang tinggi dan sensitif terhadap cahaya pada aplikasi foto yang di-coating secara aktif, oleh karena itu dengan gelatin dari ikan mempunyai keuntungan langsung dapat digunakan tanpa perlakuan yang rumit pada aplikasinya, serta dapat digunakan pada container yang sama untuk beberapa hari pemakaian.

Anonimous (2006), gelatin digunakan sebagai bahan makanan (food aditif), yang berfungsi untuk pertumbuhan otot precursor dari keratin, sebagai penambah rasa venak, dengan kandungan lemak yang bebas (rendah), sehingga dapat mengurangi energi yang dikonsumsi tubuh tanpa ada pengaruh yang negatif. Oleh karena itu dapat mengatasi penyakit yang disebabkan karena kegemukan, dengan cara membantu mengurangi enegi karena kelebihan lemak, para pengolah industry pangan dapat mengkreasikan makanan dengan rendah kalori yaitu dengan menambahkan gelatin yang nota bene tidak ada kandungan lemak dan gula, karena gelatin dapat mengikat sejumlah besar air dan dapat membantu member rasa kenyang setelah mengkonsumsi, dapat juga menggantikan kalori yang biasanya berlebihan 
pada es krim (Anonimous, 2006), selanjutnya dikatakan bahwa gelatin dapat mengkreasikan makanan yang bergizi pada pasien, karena nutrisinya tinggi dan rendah untuk dicerna serta digunakan pada makanan cair dengan rasa enak juga mudah diabsorbsi, dengan demikian dapat dihubungkan dengan kesehatan masyarakat.

\section{KESIMPULAN}

Gelatin adalah hasil hidrolisa protein yang terdapat pada tulang dan kulit ikan, mudah dicerna oleh tubuh manusia, adalah intake yang cepat dalam tubuh. Mempunyai sifat rendah kalori, protein tinggi, serta bebas kandungan gula. Gelatin dapat diaplikasikan dengan mudah untuk keperluan industri pangan, farmasi dan fotografi.

\section{DAFTAR PUSTAKA}

Anonymous, 2005. http://www.gelatin.co.za/gltn1.htm1. 2006a. http://wwwgwlatin-gmia.com/html/ gelatin_health.html.

2006b. http://norlandprod.com/techrpts/ fishgelrpt. html.

Arnesen, Jan.A and Gildberg.A 2001. Preparation and Characterization of Gelatin from The skin Harp Seal (Phoca groendlandica).

Gomez-Guillen., Turnay J, Fernandez MD, Ulmo N, Lizare MA, Montero P. 2002. Structural and Physical Properties of gelatin extracted from different Marine species. Food Hidrtocolloids. 16 (2002). P: 25-34.

Jongjareonrah A, Benyahal S, Visesanyuon W, Tanaka M. 20 (2006).p.1216.

Ockerman HW and Hansen CL. 2000. Animal By-product Processing \&Utilization.

Wahyuni M, Peranginangin R. http://ikanmania. wordpress.com/2008. 